\title{
Glossary of abbreviations and terms
}

\begin{tabular}{|c|c|}
\hline ATA & Advance Tax Agreement \\
\hline ATAD & Anti-Tax Avoidance Directive \\
\hline BEPS & Base Erosion and Profit Shifting \\
\hline BTC & Beneficial Tax Competition \\
\hline Capital & Financial capital or asset possessing monetary value \\
\hline $\mathrm{CA}$ & Court of Appeal \\
\hline CBCR & Country-by-Country Reporting \\
\hline CERF & Cambridge Endowment for Research in Finance \\
\hline CFA & Committee on Fiscal Affairs \\
\hline CFC & Controlled Foreign Company \\
\hline CIGA & Core Income Generating Activity \\
\hline CIT & Corporate Income Tax \\
\hline CJEU & Court of Justice of the European Union \\
\hline CMAAT & $\begin{array}{l}\text { Multilateral Convention on Mutual Administrative } \\
\text { Assistance in Tax Matters }\end{array}$ \\
\hline CRS & Common Reporting Standard \\
\hline DTT & Double Tax Treaty \\
\hline ECOFIN & Economic and Financial Affairs Council \\
\hline ECPR & European Consortium for Political Research \\
\hline ECR & European Court Reports \\
\hline $\begin{array}{l}\text { Effective resi- } \\
\text { dence taxation }\end{array}$ & $\begin{array}{l}\text { Techniques or mechanisms that successfully enable the } \\
\text { residence state to achieve its desired goal of levying tax } \\
\text { on its tax residents }\end{array}$ \\
\hline $\begin{array}{l}\text { Effective source } \\
\text { taxation }\end{array}$ & $\begin{array}{l}\text { Techniques or mechanisms that successfully enable the } \\
\text { source state to achieve its desired goal or levying tax on } \\
\text { income that originates within it }\end{array}$ \\
\hline EIM & European Internal Market \\
\hline
\end{tabular}


EoI

EU

EUCOTAX

FATCA

FDI

FFI

FHTP

FIF

G20

GDP

Global Forum

Government behavioural concept

HL

HTC

IBFD

ICJ

ICTD

IMF

IP

IRS

MLI

MNE

OECD

OJ

PE

Potentially taxable events
Exchange of Information

European Union

European Universities Cooperating on Taxes

Foreign Account Tax Compliance Act

Foreign Direct Investment

Foreign Financial Institution

Forum on Harmful Tax Practices

Foreign Investment Fund

Group of Twenty

Gross Domestic Product

Global Forum on Transparency and Exchange of Information for Tax Purposes

Fiscal behaviours of states through the instrumentality of governments

House of Lords

Harmful Tax Competition

International Bureau of Fiscal Documentation

International Court of Justice

International Centre for Tax and Development

International Monetary Fund

Intellectual Property

Inland Revenue Service

Multilateral Instrument

Multinational Enterprise

Organisation for Economic Co-operation and Development

Official Journal

Permanent Establishment

Events that can be taxed when they are attracted or retained by the state. These events may or may not be taxed by the state. They are events that receive favourable tax treatment in a state compared to another state, e.g. capital flows 


$\begin{array}{ll}\text { PTR } & \text { Preferential Tax Regime } \\ \text { R\&D } & \text { Research and Development } \\ \text { SDGs } & \text { Sustainable Development Goals } \\ \text { SSRN } & \text { Social Science Research Network } \\ \text { State } & \text { An autonomous taxing jurisdiction regarding the } \\ & \text { corporate income taxation and it includes independent } \\ & \text { territories of other countries } \\ \text { TCJA } & \text { Tax Cuts and Jobs Act } \\ \text { TCR } & \text { Thin Capitalisation Rule } \\ \text { TFEU } & \text { Treaty on the Functioning of the European Union } \\ \text { TFJs } & \text { Tax Flight Jurisdictions } \\ \text { TIEA } & \text { Tax Information Exchange Agreement } \\ \text { UK } & \text { United Kingdom } \\ \text { UN } & \text { United Nations } \\ \text { US } & \text { United States } \\ \text { USC } & \text { United States Code } \\ \text { VAT } & \text { Value Added Tax } \\ \text { Vol } & \text { Volume } \\ \text { WHT } & \text { Withholding Tax } \\ \text { WTO } & \text { World Trade Organization }\end{array}$


Chidozie G. Chukwudumogu - 9781802200355 Downloaded from PubFactory at 04/26/2023 12:47:37AM 